\title{
In Memoriam David Thomas Clarkson (1938-2021)
}

\author{
Hans Lambers ${ }^{\circledR}$
}

Received: 7 December 2021 / Accepted: 13 December 2021 / Published online: 11 February 2022

(C) The Author(s) 2022

Keywords David Thomas Clarkson · calcicole and calcifuge species $\cdot$ plant mineral nutrition

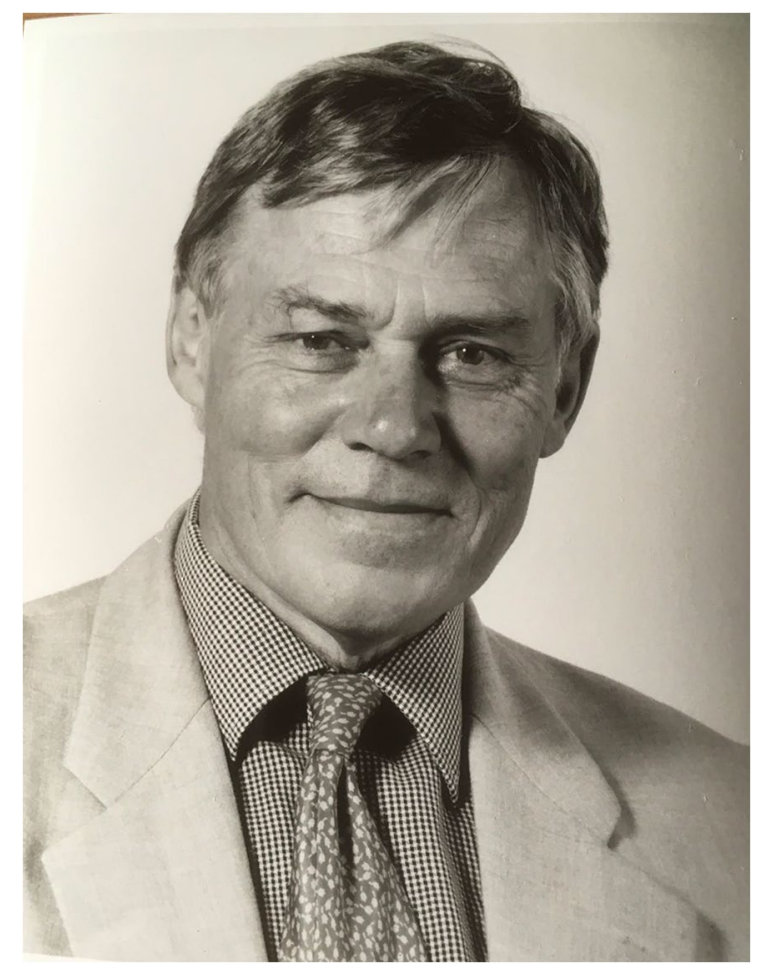

Responsible Editor: Philip John White.

H. Lambers $(\bowtie)$

School of Biological Sciences (MO84), The University of Western Australia, Perth, WA 6009, Australia e-mail: hans.lambers@uwa.edu.au
I am writing this In Memoriam of David Clarkson as someone who admired his work and through my interactions developed a deep friendship with David. I took advantage of additional information provided by his wife Dilys, who also became a dear friend Marion and I loved to meet.

David was born in 1938 in Bexley, Kent, United Kingdom. After leaving school at 16, he worked for three years as a student apprentice in the pharmaceutical industry before deciding to qualify to enter the university of Exeter and study Botany and Chemistry. Six years later, he completed his $\mathrm{PhD}$ and then had his first postdoctoral fellowship at the university of East Anglia. Following this, he was a postdoc at Brookhaven National Laboratory in New York and returned to the UK in 1967 to work at Letcombe Laboratory in Wantage.

Throughout his career, David has been the beneficiary of many international contacts and maintained strong links with universities and institutions across the world, in particular with Australia, Lisbon, Bayreuth, the Netherlands, China, India, Bangladesh, Spain and France. In 1978, he received a Royal Society/Soviet Academy of Sciences award for extensive travels in the USSR, which he greatly appreciated. He loved to travel, and his research gave ample opportunities for this. He twice took his family for sabbatical years abroad. First in 1981/82 to Brisbane where he worked with Dr Frank Smith at CSIRO, division of Tropical Crops and Pastures, and then in 1998/99 to Montpellier, France to work in the laboratory of Dr Claude Grignon at INRA. 
David retired from academic life in 1998. He did continue with some of his collaborations after this point, but had taken the decision to do something completely different in his retirement, and returned to college to study cabinet making. He was as proud of his City and Guilds Advanced diploma in furniture making as he was of his many scientific and academic accolades. As well as this, he enjoyed painting and writing, singing and gardening and liked to keep in touch and follow the careers of his students and colleagues.

I knew of David's work since well before I got to meet him in person. At the Department of Plant Physiology, University of Groningen, where I did my PhD, David Clarkson was a wellknown name, because of his groundbreaking work on ion transport and plant nutrition, especially his early work on calcicole and calcifuge grass species (Clarkson 1965; Clarkson 1966). The Nitrogen Group, led by Dr Jurien J. Hofstra, was especially interested in his work on nitrogen uptake and metabolism (Clarkson and Warner 1979; Deane-Drummond et al. 1979).

The first time I met this 'legend' was just before I was to defend my $\mathrm{PhD}$ thesis, when I attended the $13^{\text {th }}$ University of Nottingham Easter School in Agricultural Science held at Sutton Bonington in England on April 2-5, 1979. His presentation, which appeared in the proceedings of the meeting (Clarkson 1981), made a deep impression on me and I have used what I first learned from David at that meeting in three editions of my textbook and several reviews (Lambers 2022; Lambers et al. 2008; Lambers and Oliveira 2019; Lambers and Plaxton 2015; Lambers and Shane 2007; Lambers et al. 2006; Suriyagoda et al. 2014).

David was a keynote speaker at a symposium on nitrogen metabolism organised to celebrate the retirement of Jurien Hofstra, one of my $\mathrm{PhD}$ supervisors, at the University of Groningen. His outstanding presentation was published as a solid chapter (Clarkson 1986) in the proceedings of that symposium (Lambers et al. 1986). This contribution from the symposium led to further interactions with David and one of his students, David Cooper, and Ineke Stulen's group (Barneix et al. 1988; Cooper and Clarkson 1989; Ter Steege et al. 1998).
I met David during numerous conferences, but a personal highlight was at the $3^{\text {rd }}$ International Symposium on Inorganic Nitrogen Assimilation, held in Tiberias, Israel, 6-11 September 1992. David and I were asked to debate an issue on which we actually both fully agreed, and we decided a bottle of wine was called for on the shore of Lake Tiberias (or Sea of Galilee); I recall John Raven joining. Fortified with Dutch courage, we embarked on the debate, and managed to put up a convincing show for our audience.

When I was Professor of Ecophysiology at Utrecht University (1985-1998), I nominated David for the rotating F.C. Donders Chair, which he held in 1995, giving his 'Oratie' (Public address), entitled, "The great race against time; hungry populations and the new biology", in May. For some of the time, David stayed with us, in our house in Maarssen. This was a historic house, originally built in the $17^{\text {th }}$ century as the local Courthouse, but was also known as the Inn of the Black Boar, situated along the beautiful river Vecht, in the centre of the Netherlands. For some of the time, David also was a guest of Owen Atkin, who then worked as a postdoc with me. Owen wrote: "David was excellent company. I remember him having to deal with his 'new' heart pacing device that required body movement to work properly - something that was an issue for him because he rode a bike so smoothly into work that the pacemaker didn't activate, and he was progressively $\mathrm{O}_{2}$ starved (he joked about it!). David always had time for early-career researchers, and this was a recurring theme: I remember him giving me some good career advice at a time when I was not so sure what lay ahead." Another example is from Tim Colmer from the time he did his $\mathrm{PhD}$ at UC Davis, USA, in the early 1990s "I remember fondly an afternoon at the swimming pool at Davis when I had the opportunity to chat with David. He visited Davis, where he gave a great a seminar, and I then bumped into him at the pool the next afternoon. David was generous with his time (a couple of hours!) to chat with me about a wide range of topics (including wood-working, as well as plant science)."

David's presence at Utrecht University was a very pleasant and productive time for all involved, including many students. One of my 
$\mathrm{PhD}$ students started a project on nitrate transport in fast- and slow-growing grass species which took both of us to Long Ashton Laboratory, Bristol, UK, where David had been relocated. This led to a publication that explained the relatively fast respiration rates of both slow-growing grasses (Scheurwater et al. 1999) and cork oak (Mata et al. 2000). It solved a mystery that had puzzled my group in Utrecht for quite some time (Lambers et al. 1998a, b; Scheurwater et al. 1998). David took advantage of the whole-plant gas-exchange facilities we had at Utrecht University, and pursued his interest in sulfur metabolism there (Gilbert et al. 1997).

Given his international reputation as one of the most widely respected plants scientists in ion transport and plant nutrition, I nominated David for an Honorary Doctorate at the University of Western Australia in Perth, where I had moved to in 1998. This was strongly supported by Professor Alan Robson, who then was Deputy Vice Chancellor at the University of Western Australia. Alan, in earlier days, was also active and highly regarded in plant nutrition research, and knew David from his time at Letcombe Laboratory (Clarkson 1985; Clarkson and Hanson 1980; Clarkson and Scattergood 1982; Cogliatti and Clarkson 1983). This institute was renowned for the concentration of excellent scientists working on plant nutrition, before it was closed, and David moved to Long Ashton Research Station. The panel that made the decision to award him his Honorary Doctorate at the University of Western Australia acknowledged that David had made an outstanding contribution to our understanding of the mineral nutrition of both wild and cultivated plants, through his many primary papers, his authoritative reviews, and his textbook, entitled "Ion Transport and Cell Structure in Plants" (Clarkson 1974). Through his pioneering work, we now have a much better understanding of the acquisition and utilisation of calcium, phosphorus, nitrogen, potassium and sulfur in plants.

Like many other researchers working on plant mineral nutrition, I admired David as a scientist and treasured him as a friend. As a token of appreciation I dedicated my review for Annual Review of Plant Biology, which I wrote when he passed away to him (Lambers 2022). David will continue to occupy a special place in our memories, both as a scientist and as a dear friend.

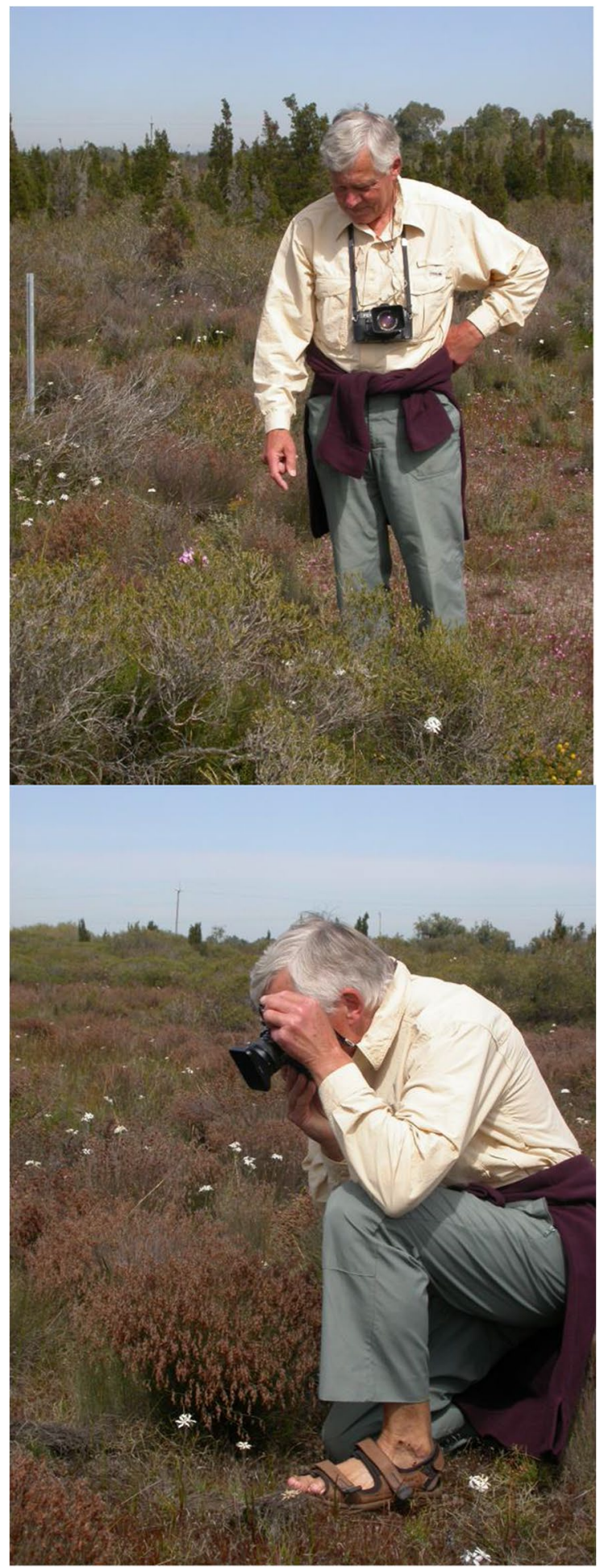


Acknowledgements I greatly appreciate the input from both Dilys Clarkson and Marion Cambridge into the In Memoriam.

Funding Open Access funding enabled and organized by CAUL and its Member Institutions.

Open Access This article is licensed under a Creative Commons Attribution 4.0 International License, which permits use, sharing, adaptation, distribution and reproduction in any medium or format, as long as you give appropriate credit to the original author(s) and the source, provide a link to the Creative Commons licence, and indicate if changes were made. The images or other third party material in this article are included in the article's Creative Commons licence, unless indicated otherwise in a credit line to the material. If material is not included in the article's Creative Commons licence and your intended use is not permitted by statutory regulation or exceeds the permitted use, you will need to obtain permission directly from the copyright holder. To view a copy of this licence, visit http://creativecommons.org/licenses/by/4.0/.

\section{References}

Barneix AJ, Cooper HD, Stulen I, Lambers H (1988) Metabolism and translocation of nitrogen in two Lolium perenne populations with contrasting rates of mature leaf respiration and yield. Physiol Plant 72:631-636. https://doi.org/ 10.1111/j.1399-3054.1988.tb09174.x

Clarkson DT (1965) Calcium uptake by calcicole and calcifuge species in the genus Agrostis L. J Ecol 53:427-435

Clarkson DT (1966) Aluminium tolerance in species within the genus Agrostis. J Ecol 54:167-178

Clarkson DT (1974) Ion Transport and Cell Structure in Plants. McGraw-Hill, London

Clarkson DT (1981) Nutrient interception and transport by root systems. In: Johnson CB (ed) Physiological Processes Limiting Plant Productivity. Butterworths, London, pp 307-314

Clarkson DT (1985) Factors affecting mineral nutrient acquisition by plants. Annu Rev Plant Physiol 36:77-115. https:// doi.org/10.1146/annurev.pp.36.060185.000453

Clarkson DT (1986) Regulation of the absorption and release of nitrate by plant cells: a review of current ideas and methodology. In: Lambers H, Neeteson JJ, Stulen I (eds) Fundamental, Ecological and Agricultural Aspects of Nitrogen Metabolism in Higher Plants Developments in Plant and Soil Sciences. Springer, Dordrecht

Clarkson DT, Hanson JB (1980) The mineral nutrition of higher plants. Annu Rev Plant Physiol 31:239-298. https://doi.org/10.1146/annurev.pp.31.060180.001323
Clarkson DT, Scattergood CB (1982) Growth and phosphate transport in barley and tomato plants during the development of, and recovery from, phosphate-stress. J Exp Bot 33:865-875. https://doi.org/10.1093/jxb/33.5.865

Clarkson DT, Warner AJ (1979) Relationships between root temperature and the transport of ammonium and nitrate ions by Italian and perennial ryegrass (Lolium multiflorum and Lolium perenne). Plant Physiol 64:557-561. https:// doi.org/10.1104/pp.64.4.557

Cogliatti DH, Clarkson DT (1983) Physiological changes in, and phosphate uptake by potato plants during development of, and recovery from phosphate deficiency. Physiol Plant 58:287-294. https://doi.org/10.1111/j.1399-3054. 1983.tb04183.x

Cooper HD, Clarkson DT (1989) Cycling of amino-nitrogen and other nutrients between shoots and roots in cereals-a possible mechanism integrating shoot and root in the regulation of nutrient uptake. J Exp Bot 40:753-762. https:// doi.org/10.1093/jxb/40.7.753

Deane-Drummond CE, Clarkson DT, Johnson CB (1979) Effect of shoot removal and malate on the activity of nitrate reductase assayed in vivo in barley roots (Hordeum vulgare cv. Midas). Plant Physiol 64:660-662. https://doi. org/10.1104/pp.64.4.660

Gilbert SM, Clarkson DT, Cambridge M, Lambers H, Hawkesford MJ (1997) $\mathrm{SO}_{4}{ }^{2-}$ deprivation has an early effect on the content of ribulose-1,5-bisphosphate carboxylase/oxygenase and photosynthesis in young leaves of wheat. Plant Physiol 115:1231-1239. https://doi.org/10.1104/pp.115.3.1231

Lambers H (2022) Phosphorus acquisition and utilization in plants. Annu Rev Plant Biol 73:125738. https://doi.org/10. 1146/annurev-arplant-102720-125738

Lambers H, Oliveira RS (2019) Plant Physiological Ecology, 3rd edn. Springer, Cham

Lambers H, Plaxton WC (2015) Phosphorus: back to the roots. In: Plaxton WC, Lambers H (eds) Annual Plant Reviews Volume 48: Phosphorus Metabolism in Plants. WileyBlackwell Publishing, Chicester, pp 3-22

Lambers H, Shane MW (2007) Role of root clusters in phosphorus acquisition and increasing biological diversity in agriculture. In: Spiertz JHJ, Struik PC, Van Laar HH (eds) Scale and Complexity in Plant Systems Research: GenePlant-Crop Relations. Springer, Dordrecht, pp 237-250

Lambers H, Chapin FS, Pons TL (1998) Plant Physiological Ecology. Springer-Verlag, New York

Lambers H, Scheurwater I, Mata C, Nagel OW (1998) Root respiration of fast- and slow-growing plants, as dependent on genotype and nitrogen supply: a major clue to the functioning of slow-growing plants. In: Lambers H, Poorter H, Van Vuuren MMI (eds) Inherent Variation in Plant Growth Physiological Mechanisms and Ecological Consequences. Backhuys, Leiden, pp 139-157 
Lambers H, Shane MW, Cramer MD, Pearse SJ, Veneklaas EJ (2006) Root structure and functioning for efficient acquisition of phosphorus: matching morphological and physiological traits. Ann Bot 98:693-713. https://doi.org/10. 1093/aob/mcl114

Lambers H, Chapin FS, Pons TL (2008) Plant Physiological Ecology, 2nd edn. Springer, New York

Lambers H, Stulen G, Neeteson JJ (eds) (1986) Fundamental, ecological and agricultural aspects of nitrogen metabolism in higher plants: proceedings of a symposium organized by the Department of Plant Physiology, University of Groningen and the Institute for Soil Fertility, Haren, 9-12 April 1985. Martinus Nijhof/Dr W. Junk, Dordrecht

Mata C, van Vemde N, Clarkson D, Martins-Loução M, Lambers H (2000) Influx, efflux and net uptake of nitrate in Quercus suber seedlings. Plant Soil 221:25-32. https:// doi.org/10.1023/A:1004785331462

Scheurwater I, Cornelissen C, Dictus F, Welschen R, Lambers H (1998) Why do fast- and slow-growing grass species differ so little in their rate of root respiration, considering the large differences in rate of growth and ion uptake? Plant Cell Environ 21:995-1005. https://doi.org/10.1046/j. 1365-3040.1998.00341.x
Scheurwater I, Clarkson DT, Purves JV, Van Rijt G, Saker LR, Welschen R, Lambers H (1999) Relatively large nitrate efflux can account for the high specific respiratory costs for nitrate transport in slow-growing grass species. Plant Soil 215:123-134. https://doi.org/10.1023/A:1004559628 401

Suriyagoda LDB, Ryan MH, Renton M, Lambers H (2014) Plant responses to limited moisture and phosphorus availability: a meta-analysis. Adv Agron 124:143-200. https:// doi.org/10.1016/B978-0-12-800138-7.00004-8

Ter Steege MW, Stulen I, Wiersema PK, Paans AJM, Vaalburg W, Kuiper PJC, Clarkson DT (1998) Growth requirement for $\mathrm{N}$ as a criterion to assess the effects of physical manipulation on nitrate uptake fluxes in spinach. Physiol Plant 103:181-192. https://doi.org/10.1034/j.1399-3054.1998. 1030205.x

Publisher's note Springer Nature remains neutral with regard to jurisdictional claims in published maps and institutional affiliations. 